\title{
Bedrock Geologic Map of the Windham Quadrangle, Rockingham and Hillsborough Counties, New Hampshire
}

By

Gregory J. Walsh and Stewart F. Clark, Jr.

U.S. Geological Survey

Montpelier, Vermont

Open-File Report 99-8

OF-99-8-A (paper map and text)

OF-99-8-B (computer files)

1999

Prepared in cooperation with the New Hampshire Department of Environmental Services, Water Division

This report is preliminary and has not been reviewed for conformity with U.S. Geological Survey editorial standards (or with the North American Stratigraphic Code). Any use of trade, product, or firm names is for descriptive purposes only and does not constitute endorsement by the USGS. Although this database has been used by the U.S. Geological Survey, no warranty, expressed or implied, is made by the USGS as to the accuracy and functioning of the database and related program material, nor shall the fact of distribution constitute any such warranty, and no responsibility is assumed by the USGS in connection therewith.

The text and map are part $A$ and the database is part $B$ of this report. Both parts are available from http://pubs.usgs.gov/openfile/of99-8/ 


\section{INTRODUCTION}

The bedrock of the Windham quadrangle consists primarily of Ordovician and Silurian metasedimentary rocks of the Berwick Formation. Regionally, the Berwick Formation is part of the Merrimack Group or Trough. The metasedimentary rocks are intruded by Silurian rocks of the Ayer Granodiorite, Devonian granitic rocks of the New Hampshire Plutonic Suite, and Mesozoic diabase and lamprophyre dikes of the White Mountain Plutonic-Volcanic Suite.

This work represents the first 1:24,000 quadrangle-scale mapping in the Merrimack Trough of New Hampshire. The purpose of this report is to present new results on the stratigraphic and structural relationships in the Merrimack Trough.

\section{PREVIOUS WORK}

The State geologic map by Lyons and others (1997) represents the most recent compilation of the bedrock of the Windham quadrangle. The compilation on the State map represents work from a field trip guidebook by Lyons and Bothner (1989) and 1:62,500 scale mapping as part of the southeastern quadrant of the Manchester, New Hampshire 15-minute quadrangle by Sriramadas (1966). The work by Lyons and Bothner (1989) and Lyons and others (1997) differs from Sriramadas (1966) in the assignment of different names to the metasedimentary rocks of the Merrimack Trough. According to Sriramadas (1966), most of the rocks in the Windham area belong to the Eliot Formation. His stratigraphic sequence went from the Eliot, at the base in the southeastern corner of the area, stratigraphically upward into the Berwick in the northwestern part of the Windham quadrangle, north and west of the Hudson pluton. Sriramadas (1966) subdivided the Eliot and Berwick into upper and lower members based on the percentage of interbedded calc-silicate rock, which he called lime-silicate granulites. His percentages are as follows: lower Eliot (10\%), upper Eliot (25\%), lower Berwick (5\%), and upper Berwick (15\%). Sriramadas (1966) interpreted the entire section as the southeastern limb of a major syncline with the axis through the Devonian Littleton Formation located north and west of the 7.5-minute Windham quadrangle. According to Lyons and Bothner (1989) and Lyons and others (1997), the metasedimentary rocks in the Windham quadrangle belong to the Berwick Formation. In their model, the Berwick is the lowermost unit in the Merrimack Group and is depositionally overlain by the Eliot and then the Kittery Formations to the northeast of the Windham area.

\section{AGE OF THE ROCKS}

The metasedimentary rocks of the Berwick Formation are the oldest rocks in the quadrangle, but the age is based on limited evidence. No fossils have been reported from the Berwick Formation, but Silurian graptolites have been found in the correlative Vassalboro Formation of Maine (Pankiwskyj and others, 1976). Detrital zircons from the Berwick have $\mathrm{Pb} / \mathrm{Pb}$ ages as young as $440 \mathrm{Ma}$ (Aleinikoff and others, 1995). In southeastern New Hampshire, the Newburyport Complex intrudes the Kittery Formation and has a U/Pb age of $418 \pm 1 \mathrm{Ma}$ (Lyons and others, 1997). According to Lyons and others (1997), the Kittery is the uppermost unit in the Merrimack Trough, stratigraphically above the Elliot and Berwick Formations. These findings constrain the Berwick Formation to an Ordovician to Silurian age. Zartman and Naylor (1984) reported a $433 \pm 5 \mathrm{Ma} \mathrm{U} / \mathrm{Pb}$ age (Silurian) from the Ayer Granodiorite in Massachusetts. The Ayer intrudes the Berwick Formation in the Windham quadrangle and, if the previously stated ages are considered accurate, implies that the Berwick may be constrained between 440 
Ma and 433 Ma. Rocks of the Chelmsford Granite are the next youngest rocks in the area and intrude the Berwick and the Ayer. Zartman and Naylor (1984) determined a Pb/Pb age of $389 \pm 5 \mathrm{Ma}$ for the Chelmsford Granite in Massachusetts. Similar granitic intrusions are present throughout the area, and a biotite granite dike exposed on Interstate 93 was dated at $381 \pm 2 \mathrm{Ma}$ (station 122 from Table 1 of Lyons and others, 1997). These granitic dikes, and the muscovite granite of the Hudson pluton, have similar cross cutting relationships with the Berwick and the Ayer and are assigned a Devonian age. Postmetamorphic diabase and lamprophyre dikes of the White Mountain Plutonic-Volcanic Suite intruded all rocks in the area sometime during the Mesozoic (Foland and Faul, 1977).

\section{STRATIGRAPHY}

Three metasedimentary rock units were mapped in the Windham area, all of which belong to the Berwick Formation. The most widespread unit (SOb) consists of interbedded biotite-plagioclase-quartz granofels, schist, and calc-silicate rocks. The SOb unit crops out south and east of the Hudson pluton. Variability in the SOb unit is expressed by the amount of laminated granofels, or gneiss, and the percentage of calc-silicate rocks. Locally, laminated varieties of the SOb unit are composed of closely spaced ( 2 to $3 \mathrm{~mm}$ ), white-weathering calc-silicate layers alternating with gray, biotite-plagioclase-quartz granofels layers. The laminations are parallel to bedding and define the bed-parallel S1 schistosity. Where the unit is not laminated, it typically consists of more massive granofels layers interbedded with less abundant schist. Typical exposures of the SOb unit can be seen in roadcuts along Interstate 93 and along Route 111 in the vicinity of Indian Rock. Calc-silicate rocks occur as layers, lenses, and pods of granofels or foliated gneiss throughout the SOb unit. Their distribution is not consistent, and their abundance typically varies from approximately 5 percent, or less, up to 30 percent, and locally up to 50 percent. This variability is in contrast to what Sriramadas (1966) reported, and we could not use the distribution or abundance of calc-silicate rocks as mapping criteria.

In the northwestern part of the map, north and west of the Hudson pluton, a well-bedded variety of the Berwick crops out (SObw). The SObw unit is compositionally similar to the SOb unit, but it is distinctly well bedded, unlike SOb. Bedding typically is 5 to $15 \mathrm{~cm}$ thick, but ranges up to $40 \mathrm{~cm}$. Bedding is planar and continuous for many tens of meters in roadcuts in the vicinity of the Interstate 93 and Route 102 interchange in Londonderry. In addition to the different bedding characteristics, the SObw unit is at a lower metamorphic grade (biotite) than the SOb unit (garnet). Generally, the SObw unit contains approximately 5 percent calc-silicate rocks, which largely occur as granofels, not gneiss, due to the lower metamorphic grade. The percentage of calc-silicate granofels is somewhat less in the SObw unit than in the SOb unit, which contrasts to what is shown on the State map by Lyons and others (1997). On the State map, the unit SObc is described as a Berwick unit that contains more calc-silicate (15 percent) than the rest of the formation (5 percent). Our findings are exactly the opposite, and our contact also does not agree with the State map. The contact on the State map between SObc and the remainder of the Berwick (SOb) is drawn approximately $2.5 \mathrm{~km}$ northwest of the Hudson pluton. We did not detect any lithological difference in the Berwick in this area. Furthermore, although we map two separate, major Berwick units (SOb and SObw), we show the Hudson pluton intervening between the two. If the Hudson pluton were not there we would have had a difficult time separating the two units with a high degree of confidence, largely as a consequence of the small size and lack of abundant outcrops in the area.

A third, minor unit in the Berwick is the quartzite and granofels unit (SObq). The unit is characterized by the presence of quart-rich feldspathic quartzite and quartzite beds interbedded with more typical SOb rocks. The bedding is generally well defined, and beds range in thickness from several $\mathrm{cm}$ to $1 \mathrm{~m}$. Two belts of SObq crop out in the area, one in the northwestern part and the other in the southeastern part of the map. Typcial exposures occur (1) in a housing development approximately 0.3 
$\mathrm{km}$ west of Beaver Brook and $1.9 \mathrm{~km}$ south-southeast of the Interstate 93 and Route 102 interchange, and (2) $0.7 \mathrm{~km}$ at $027^{\circ}$ from the intersection of Brady Avenue and Route 38 .

\section{IGNEOUS ROCKS}

At least three phases of igneous intrusive rocks are present in the area: (1) Silurian intrusive rocks of the Ayer Granodiorite, (2) Devonian granitic rocks of the New Hampshire Plutonic Suite, and (3) Mesozoic diabase and lamprophyre dikes of the White Mountain Plutonic-Volcanic Suite.

\section{Ayer Granodiorite}

The Ayer Granodiorite contains four mappable phases: (1) microcline augen granodiorite to granite gneiss (Sag), (2) granodiorite (Sagd), (3) garnetiferous granodiorite (Sagdg), and (4) diorite (Sad). The large body of Ayer south of Rock Pond and Simpson Pond contains all four phases, with the microcline augen rock (Sag) occupying the greatest map area. Contacts within the southern body of Ayer are gradational and often interleaved, especially Sag and Sagd, parallel to the long axis of the pluton, suggesting flow layering. The interleaved aspect of Sag and Sagd is well exposed $0.1 \mathrm{~km}$ at $290^{\circ}$ from the intersection of Marblehead Road and the northwest trending access road to Rock Pond. Typical exposures of Sag are found at Deer Ledge overlooking Simpson Pond and $0.2 \mathrm{~km}$ at $156^{\circ}$ from the inlet of Golden Brook at Simpson Pond. Good exposures of Sagd are found in Windham $0.2 \mathrm{~km}$ and $0.4 \mathrm{~km}$ north of the Windham - Pelham town line along the western side of Marblehead Road.

A minor unit in the southern Ayer pluton is the diorite (Sad). The diorite is exposed along the eastern margin of the southern Ayer pluton and as a small lens in the larger Sagdg body in the east-central part of the map. The diorite is in sharp contact with the granodiorite (Sagd) and is well-exposed $0.5 \mathrm{~km}$ at $030^{\circ}$ from the intersection of Hobbs Road and Route 111A in Pelham. In the southern body of the Ayer pluton, there are only three small lenses of the garnetiferous granodiorite (Sagdg). In the east-central part of the map, however, two larger belts of Sagdg intrude the Berwick. These two bodies are quite homogeneous, unlike the southern body of the Ayer pluton. Sagdg is well exposed along Route 28 in Windham to the north and south of BM 252.

The contacts between the Ayer rocks and the Berwick generally trend to the north-northeast. A 15-m-high, vertical quarry face in the small Sagdg body on the eastern border of the map, east of Route 28, shows the contact between the Ayer and the Berwick as sub-vertical. Exposures at Deer Ledge on the northern shore of Simpson Pond show steeply, northwest dipping to sub-vertical contacts between the Ayer and the Berwick.

\section{New Hampshire Plutonic Suite}

Granitic rocks of the New Hampshire Plutonic Suite occur as abundant outcrop-scale dikes and map-scale dikes and plutons. The granitic rocks are restricted to the garnet zone; not a single dike was observed in the biotite zone. Three granitic rock units are mapped in the area: (1) binary granite and granitic pegmatite $(\mathrm{Dg}),(2)$ pegmatite $(\mathrm{Dp})$, and (3) muscovite granite (Dmg).

The Dg unit is mapped as the Chelmsford Granite in the southeastern part of the map and as unnamed dikes, sills, and small plutons throughout much of the central and eastern part of the area. The outcrop-scale dikes are generally homogenous, medium- to coarse-grained granite, but the larger masses exhibit considerable grain-size variation and are locally pegmatitic. The contacts with the Berwick Formation are always sharp at outcrop-scale, but granitic rocks get more abundant closer to the margins of the larger intrusive bodies. Locally, granitic rocks make up 50 to 80 percent of the exposure in outcrops of Berwick near the map-scale intrusions. The Dg unit is well exposed in abandoned quarries $1.5 \mathrm{~km}$ at $245^{\circ}$ from the intersection of Brady Avenue and Route 38. 
The distribution of pegmatite $(\mathrm{Dp})$ is very similar to the distribution of the binary granite and granitic pegmatite unit (Dg), with a concentration of larger plutonic bodies extending from Cobbetts Pond towards the northeastern part of the map. Contacts between the larger granitic units (Dg) and pegmatite (Dp) are transitional and are mapped where the relatively finer-grained granitic parts of the intrusion are replaced by the very coarse grained pegmatite. Outcrop-scale pegmatite dikes are generally finer grained along the margins and coarser in the centers. Compositionally, the Dg and Dp units are very similar. Typical outcrop-scale pegmatite dikes crop out $0.2 \mathrm{~km}$ north of BM 324 on Kilrea Road in the northeastern part of the quadrangle.

\section{White Mountain Plutonic-Volcanic Suite}

Mesozoic diabase and lamprophyre dikes (Md and Mdp) of the White Mountain PlutonicVolcanic Suite range in thickness from several $\mathrm{cm}$ to $40 \mathrm{~m}$. The majority of the dikes are exposed in the central part of the quadrangle, trending from the southwest corner to the northeast corner of the map. A single dike was mapped for approximately $6.5 \mathrm{~km}$ in the southwestern part of the map; the remaining dikes were mapped in individual outcrops. The $6.5 \mathrm{~km}$ long dike is well exposed in a roadcut on Route $111,3 \mathrm{~km}$ east of the junction with Route 128. A total of 28 dikes were identified in the area. The strike of 24 of the dikes could be accurately measured: 21 strike to the northeast, and three strike to the northwest (fig. 1A). The preponderance of northeast strikes suggests that the Mesozoic extension direction during intrusion was northwest to southeast, sub-parallel to the regional foliation.

\section{STRUCTURE}

\section{Ductile Structures}

The relative ages of ductile structural features in the Windham area are described in terms of their relationship to the dominant, or most visibly conspicuous, foliation at a given outcrop and in terms of their interpreted age. The relative age of the dominant foliation or fold generation is assigned to " $n$ ". Older foliations or folds are assigned to $n-1$, and younger foliations assigned to $n+1, n+2$, etc. The interpreted age of the fabrics is assigned a number designation as follows: $\mathrm{S} 0=$ bedding, $\mathrm{S} 1 / \mathrm{F} 1=$ oldest foliation and folds, S2/F2 = second oldest foliation and folds, and S3/F3 = youngest foliation and folds. The relative age assignment is an objective approach to describing fabrics at a single outcrop. This method is necessary because it is not always possible to unequivocally determine all the age relationships at every outcrop, or to correlate relative ages between different outcrops.

The oldest foliation in the area is a layer- or bed-parallel schistosity (S1) that occurs only in the Berwick Formation and contains rarely observed (two in the map area) refolded isoclinal folds. Only in the hinge region of these folds is it possible to see bedding that is not parallel to a foliation. Across most of the map area, the layer-parallel schistosity is expressed by the parallel alignment of metamorphic minerals (mostly biotite, quartz, plagioclase, and calc-silicate minerals). Where the Berwick is well laminated, the laminations define S1. Locally, this foliation is the dominant fabric in the rock and is assigned a relative age of $\mathrm{Sn}$. More commonly, however, the $\mathrm{S} 1$ foliation is deformed and transposed by the younger fabrics. The regional trend of $\mathrm{S} 1$ is generally to the northeast, but is locally folded by the younger fabrics (fig. 2D). The best-fit great circle to the deformed poles of S1 defines a $\beta$ axis which corresponds closely to the mean of the F2 fold axes (fig. 2, A and D).

The second generation planar fabric in the area varies from a spaced cleavage to a penetrative schistosity (S2) in the Berwick Formation, a gneissosity in the Ayer Granodiorite, and a gneissosity in some of the granites and pegmatites. Folds associated with the second generation fabric (F2) deform S1 and bedding and vary from open to isoclinal with generally consistent shallow plunges to both the northeast and southwest, but locally the plunges are quite steep (fig. 2A). Where the second generation foliation and folds are the dominant planar fabric in the rock, they are assigned a relative age of $\mathrm{n}$, but 


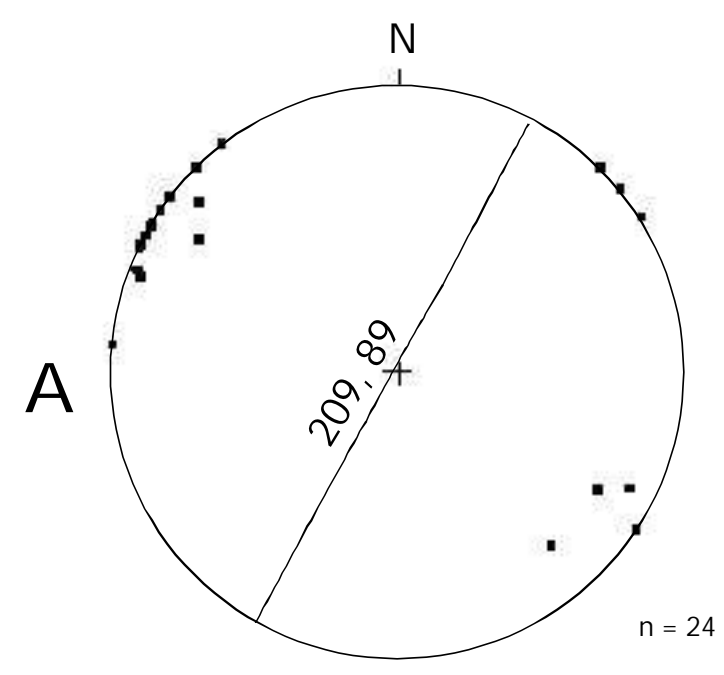

Md and Mdp dikes

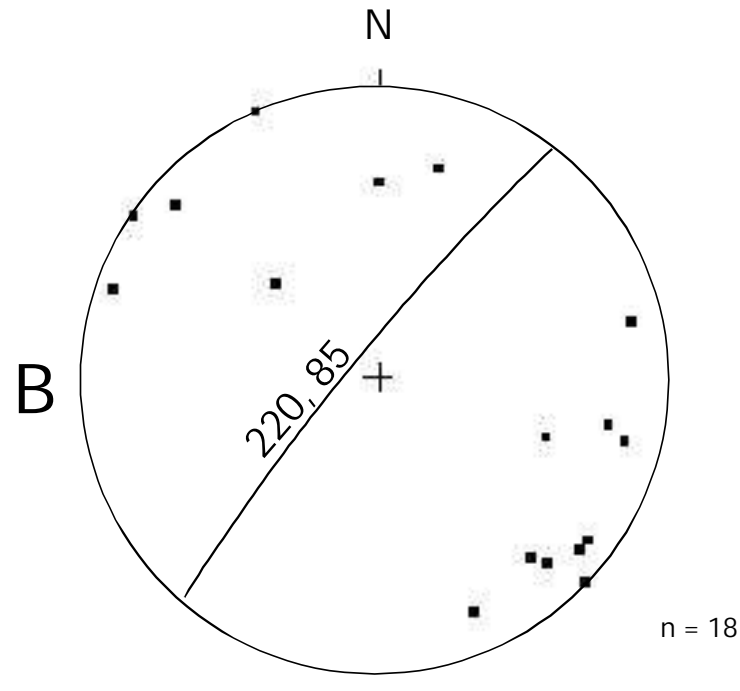

Dg dikes

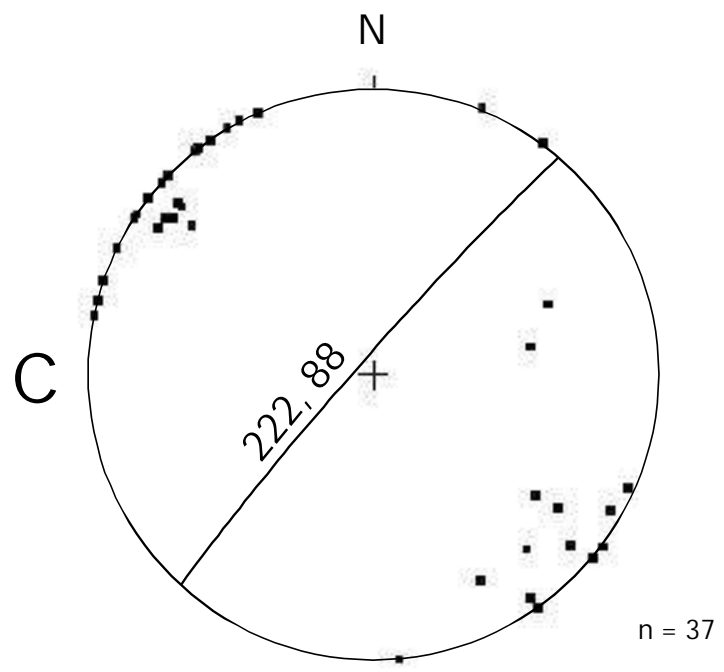

Dp dikes

Figure 1. Lower hemisphere equal area projections of pole to the strike and dip of dikes. Great circle shows the average plane; strike and dip of the plane given in right hand rule. North $=\mathrm{N}$ and the number of points in the dataset $=n$. 


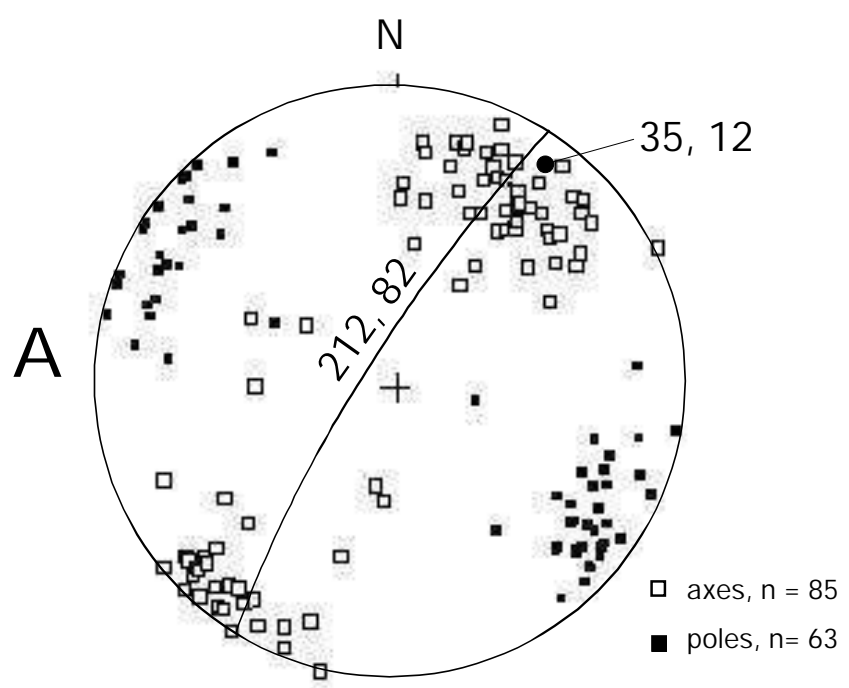

$\mathrm{Fn+1}(\mathrm{F} 2)$ : fold axes and poles to axial surfaces

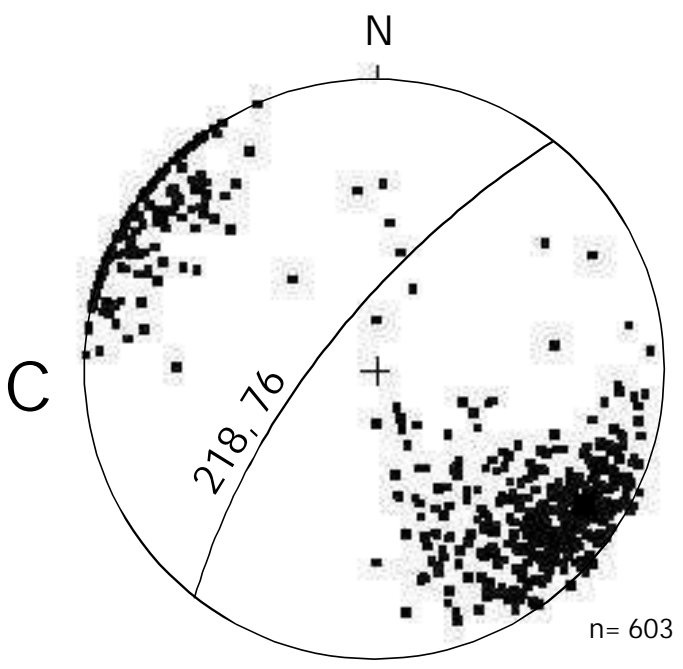

$\mathrm{Sn}$ : poles to schistosity and gneissosity

Figure 2. Lower hemisphere equal area projections of poles to the strike and dip of planes and axes to the trend and plunge of fold hinges. Diagram A: intersection lineations plotted with fold axes. Diagrams A, B, C, and E: great circle shows the average plane; strike and dip of the plane given in right hand rule. Diagram D: great circle shows strike and dip of best-fit great circle and solid circle shows trend and plunge of $\quad \beta$ axis. Diagrams $A$ and E: solid circle shows trend and plunge of average axis. North $=\mathrm{N}$ and the number of points in the dataset $=\mathrm{n}$.

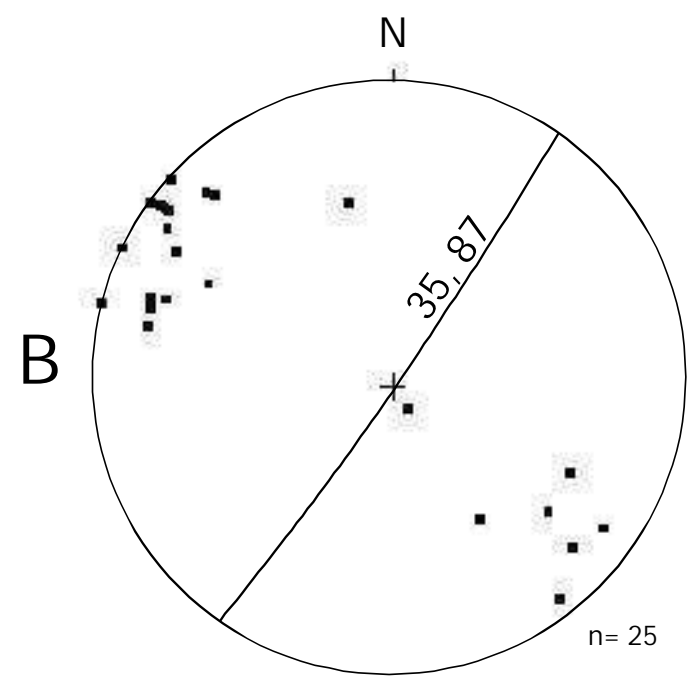

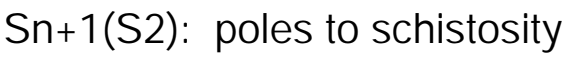 and cleavage}

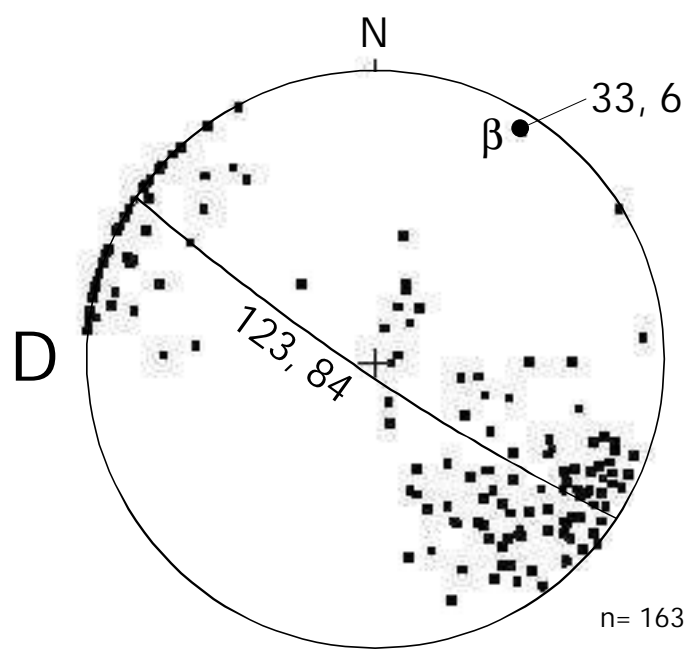

Sn (S1): poles to layer parallel schistosity

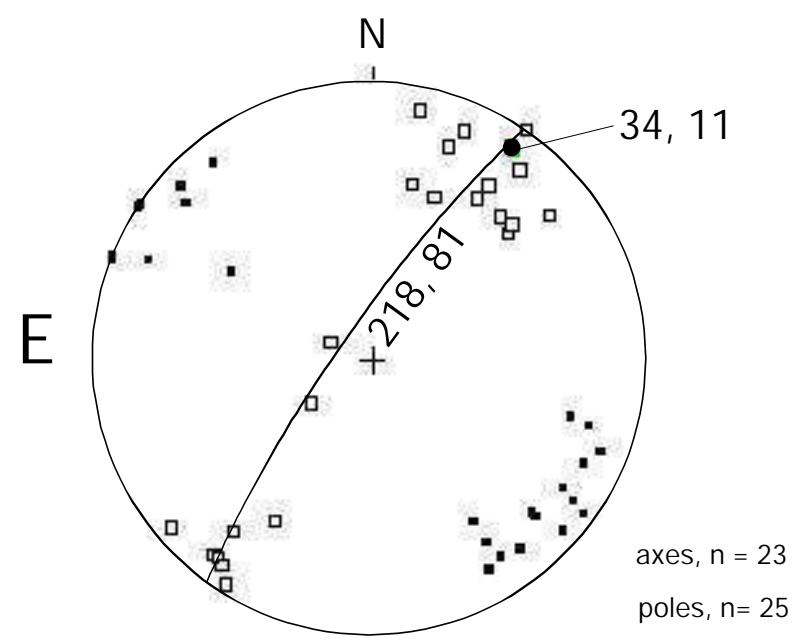

$\mathrm{Fn}$ : fold axes and poles to axial surfaces 
where they post-date the dominant fabric, they are assigned a relative age of $n+1$ (fig. 3). A comparison between the orientation of Fn folds, Fn+1 folds, and $\mathrm{Sn}+1$ schistosity and cleavage shown in Figure 2 (A, $\mathrm{B}$, and $\mathrm{E}$ ) reveals that they are the same generation fabrics, a fact that was not readily apparent at each outcrop. Locally, the F2 folds deform the bedding and S1 schistosity on a regional scale, and axial traces on the map show these locations.

$\mathrm{S} 2$ and, to a lesser degree, S1 are the dominant planar fabrics in the Berwick Formation. Locally, these two planar fabrics are parallel, and it is difficult to discern one from the other. In such places where only a single penetrative schistosity is observed, and no cross cutting relative age relationships can be discerned, a dominant foliation symbol is shown on the map.

Randomly distributed kink bands or shear bands with 10-30 cm spacing occur at five locations in the area and are visible only at outcrop scale. The kink bands are steeply dipping, and four of the five are located in the southern part of the map and strike northeast; the fifth, located in the northeastern part of the map, strikes $348^{\circ}$. Map-view rotation senses on the kink bands are clockwise or right-lateral; it is possible that these data reflect a post D2 regional right-lateral offset event. Because of the limited distribution and uncertain extent of the kink bands, we have not assigned a number to this deformation event.

The youngest ductile fabric in the area is a sub-horizontal spaced cleavage ( $\mathrm{S} 3$ or $\mathrm{Sn}+2)$ with associated symmetrical, low amplitude $(5-10 \mathrm{~cm})$ and long wavelength $(50-100 \mathrm{~cm})$ folds $(\mathrm{F} 3 \mathrm{or} F \mathrm{Fn}+2)$ (fig. 4A). This fabric is widespread throughout the area, but only visible on vertical exposures due to the shallow dips. This "accordion-like" fabric could be related to a weak D3 vertical-loading event. In large quarry and roadcut exposures, the rocks exhibit a weak exfoliation parallel to the sub-horizontal S3 cleavage and F3 axial surfaces. Much of the exfoliation, particularly in the granitic rocks, is most likely related to glacial rebound or post-Mesozoic unroofing, but appears to have utilized the sub-horizontal ductile fabric where present. Because of the limited topographic relief in the quadrangle, it was not possible to determine how the D3 fabrics changed with elevation.

\section{Brittle Structures}

Brittle fabrics in the area are shown on the brittle structure map and include joints, fractures zones, and faults. Most measurements taken in the field and recorded in the database part of this report are plotted on the brittle structure map. For cartographic clarity, however, approximately 80 joint symbols are not shown on the map. According to the State map (Lyons and others, 1997), several brittle faults are present in the area, but none of these faults could be confirmed during the course of mapping. In the southern part of the map, from Deer Ledge southwest to route 111A, there are several outcrop-scale northwest-striking fracture zones and a preponderance of northwest-striking joints that roughly correlate with the location of two faults shown on the State map. The fracture zones did not map out, however, and no displacement of the Ayer Granodiorite was recognized. The strike of 29 measured fracture zones in the quadrangle shows generally no preferred orientation (fig. 4C). The State map also shows a northeaststriking fault that enters the quadrangle north of the southwestern corner and terminates in the central part of the map. No evidence for this fault was observed, but the strike is parallel to the regional dominant foliation. Generally, steeply dipping, northwest-striking joints are the most common brittle fabric in the area (fig. 4, B and D). Outcrop-scale brittle faults and fracture zones are far less common. A total of two normal faults, two reverse faults, and three faults of undetermined offset were observed in the area. Locally, joint surfaces are coated with secondary minerals including quartz, sulfides, and zeolites. The locations of these mineralized zones are recorded in the database part of this report. The zeolites occur exclusively as fracture filling mats of white, radiating, acicular crystals in the Berwick Formation. X-ray diffraction analysis of a sample (station 4151 in the database) by XRAL Laboratories of Don Mills, Ontario, Canada indicates that the zeolites are a mixture of heulandite, stilbite, and barrerite. 
A

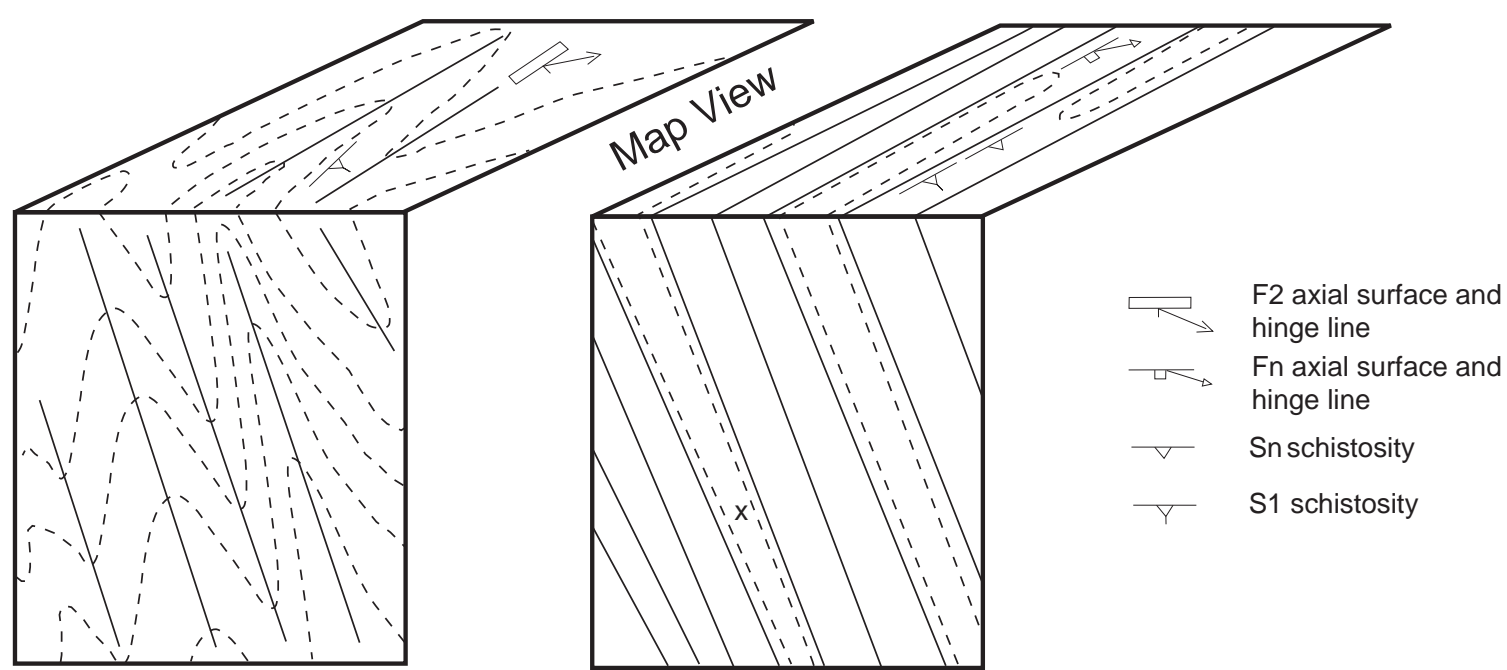

Cross Section View
$\mathrm{Sn}+1=\mathrm{S} 2$
$\ldots-\ldots \mathrm{Sn}=\mathrm{S} 1$
$\mathrm{Sn}=$ Composite S2 and S1

-... - Sn -1 = S1 (at fold hinges)

Figure 3. Schematic diagrams illustrating the different degrees of D2 fabric development and the assignment of relative ages to different fold generations. In diagram A, the dominant schistosity ( $\mathrm{Sn}$ ) is $\mathrm{S} 1$, and is deformed by $\mathrm{F} 2$ folds $(\mathrm{Fn}+1)$ which have an axial planar cleavage (S2 or $\mathrm{Sn}+1)$. Here, the S2 cleavage is a spaced cleavage, and the F2 folds are tight to near isoclinal. In diagram B, S2 is a well developed penetrative schistosity. Where S2 is penetrative, the S1 and S2 foliations become a composite fabric that is assigned a relative age of $\mathrm{Sn}$ in the field where age relationships are not readily apparent (x). At hinges of Fn folds in diagram B, the older S1 foliation is assigned a relative age of Sn-1 because it is not the dominant schistosity. 


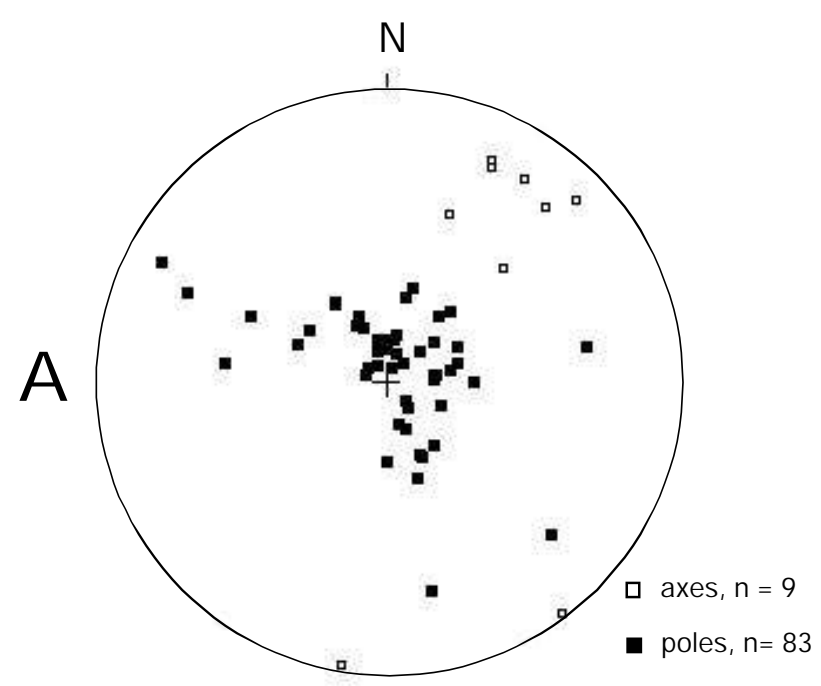

$\mathrm{Fn}+2$ (F3) and $\mathrm{Sn}+2$ (S3): fold axes, poles to cleavage, and poles to axial surfaces

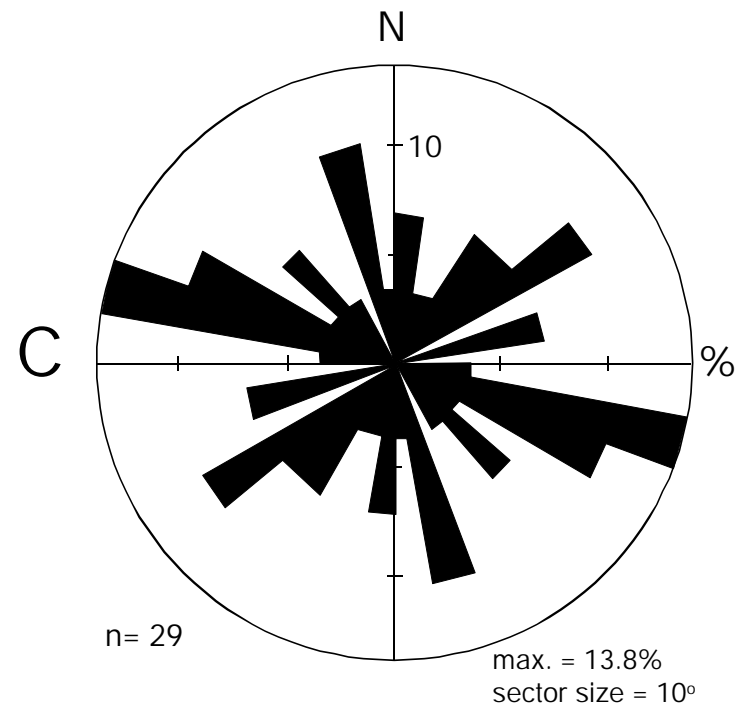

Fracture zones
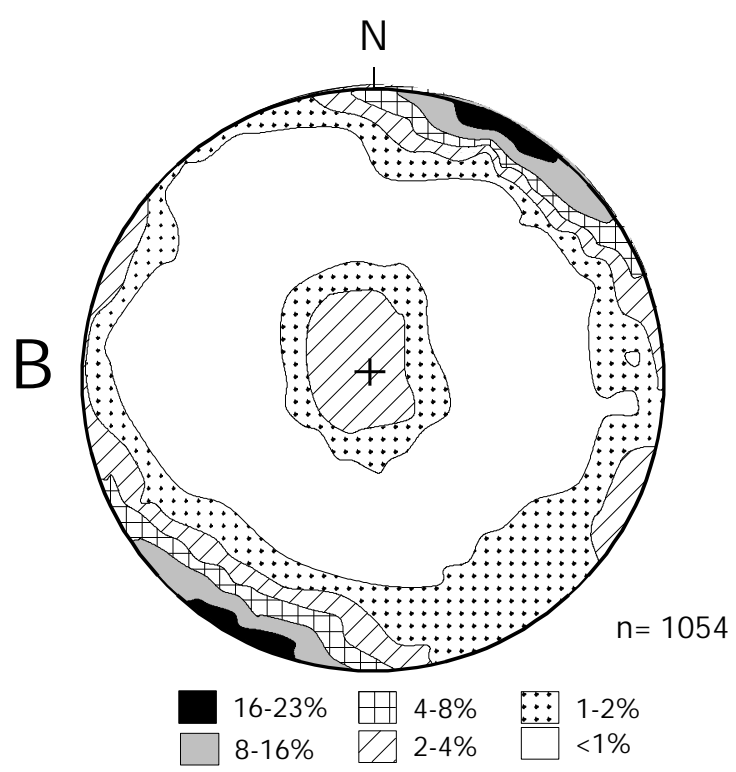

J oints

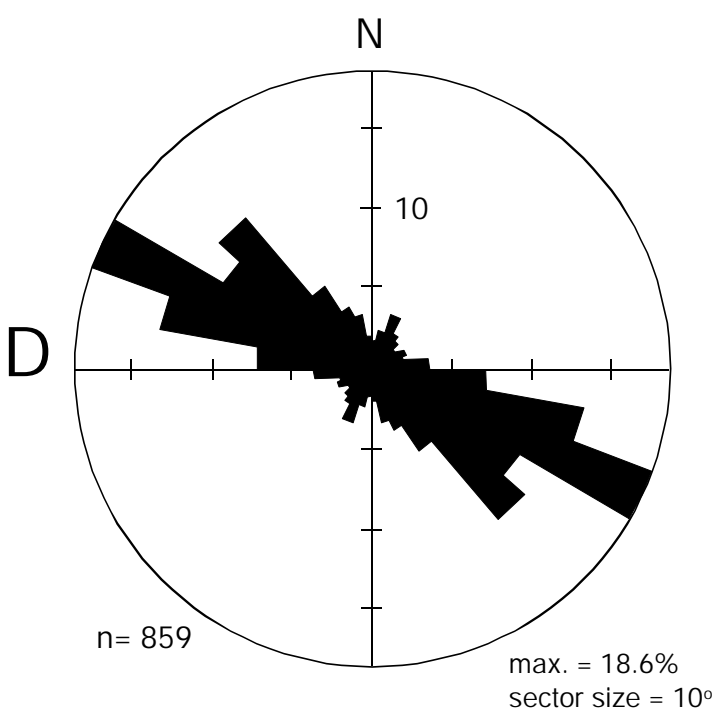

J oints with dip $>59^{\circ}$

Figure 4. Diagram A: lower hemisphere equal area projection of poles to the strike and dip of planes and axes to the trend and plunge of fold hinges. Diagram B: contoured lower hemisphere equal area projection of poles to the strike and dip of all joints. Diagrams C and D: frequencyazimuth (rose) diagrams. North $=\mathrm{N}$ and the number of points in the dataset $=\mathrm{n}$. 


\section{Glacial Features}

Glacial striations and grooves were also recorded during the course of mapping although they are not structures in the rocks. A total of 30 measurements indicate a consistent range between $142^{\circ}$ and $161^{\circ}$ with an average of $152^{\circ}$. Coincident with this trend are a number of elongate hills with the long axis parallel to this orientation. No outcrops were found on any of these hills, even where new construction provided adequate exposure. Glacial till was all that was exposed in these areas, and the hills, although not true drumlins, are probably drumlinoids. Several of the low hills occur in the vicinity of Canobie Lake, and a taller hill occurs west of Simpson Pond, Route 111A, and Golden Brook in southernmost Windham.

\section{METAMORPHISM}

Paleozoic metamorphic grade within the Windham quadrangle ranges from the biotite zone to the garnet zone. The garnet isograd runs parallel to the Hudson pluton on the northern side of the intrusion; rocks to the northwest are in the biotite zone. Biotite is widespread in the Berwick Formation and in the Paleozoic intrusive rocks, but garnet (probably almandine) is widespread only in the intrusive rocks. In the Berwick Formation, metamorphic index minerals include actinolite, epidote, and clinozoisite in the biotite zone and grossular garnet and diopside in the garnet zone. Locally in the garnet zone, however, garnet (probably almandine) occurs within more pelitic layers in the Berwick Formation, especially in the SObq unit. Calcite and dolomite are more abundant in the biotite zone. The garnet isograd shown on the map does not reflect a true isograd for pelitic rocks; rather it separates calc-silicate rocks with calcite from those with diopside. Thus, the isograd closely reflects the calcite-diopside zone change. Metamorphic veins in the biotite zone commonly consist of quartz and calcite with accessory chlorite, biotite, and muscovite, but in the garnet zone consist largely of quartz and calc-silicate minerals. The growth of peak metamorphic minerals such as garnet and diopside is largely syn- to post-D2 fabrics.

\section{DISCUSSION}

In general, the metasedimentary rocks of the Berwick Formation form a homogeneous sequence of metapsammitic and metapelitic rocks that were deposited as limey sand and mud. The three mapped Berwick units (SOb, SObq, and SObw) vary only slightly in composition and bedding characteristics. Due to limited sedimentary topping criteria, it is not possible to tell whether the well-bedded Berwick (SObw) is younger or older than the remainder of the formation (SOb and inclusive SObq). Sriramadas' (1966) original interpretation that the rocks formed the southeastern limb of a major syncline could not be validated during this study because the rocks are significantly folded twice, and topping criteria are limited. The stratigraphy in the Merrimack Trough shown on the cross-sections of the new State map by Lyons and others (1997) appears to be deformed by only a single generation of upright folds, yet our mapping shows at least two significant fold events.

Detailed analysis of topping criteria at a single roadcut of SObw located $0.5 \mathrm{~km}$ at $290^{\circ}$ from the Interstate 93 and Route 102 junction shows seven reversals of beds over a distance of approximately 30 m. (fig. 5). Here, the bedding is very planar and steeply dipping, yet reversals are common every several meters. Folds closures, however, were not observed where any of the topping reversals took place. In this area, the F2 folds and S2 cleavage are also steeply dipping and sub-vertical, sub-parallel to the bedding. Minor F2 folds, where observed, are tight but not isoclinal and have only a weak axial plane cleavage. Cleavage-bedding relationships between S2 and the layering are not consistent with the 


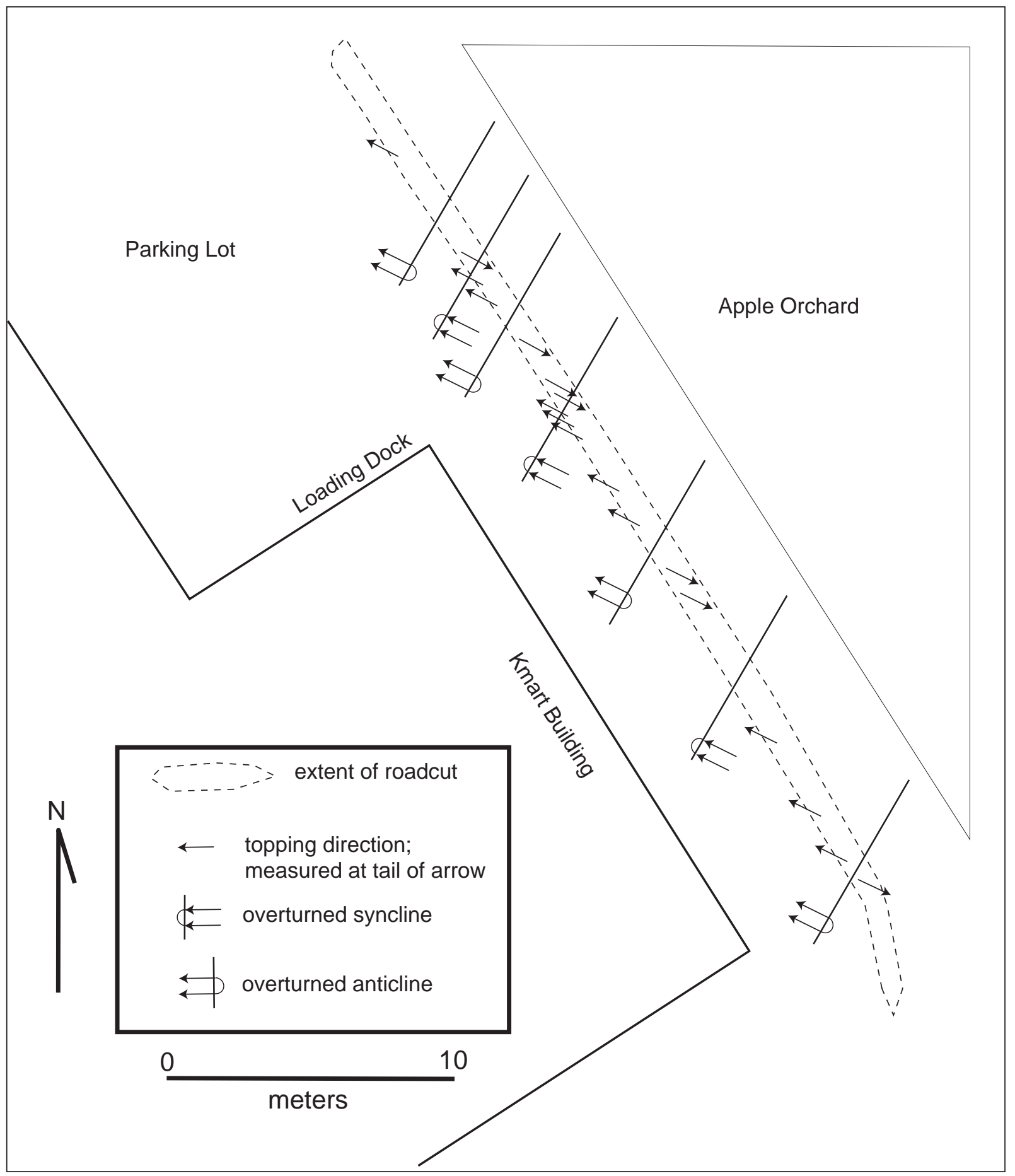

Figure 5. Sketch map showing the distribution of topping criteria in the Berwick Formation SObw unit. The beds consistently strike to the northeast and dip steeply to the northwest or are vertical. Single arrows show the topping direction based on graded beds. The data indicate seven reversals across the length of the roadcut. These reversals are interpreted to be the result of isoclinal F1 folds whose hinges are not exposed at the outcrop. The roadcut is located behind the Kmart in Londonderry, $0.5 \mathrm{~km}$ at $290^{\circ}$ from the Interstate 93 and Route 102 junction. 
reversals of tops. This evidence suggests that the major reversals are due to isoclinal F1 folds whose hinges are not exposed at the outcrop.

In the southeastern part of the quadrangle, graded bedding in the SObq unit defines a reversal that cannot be explained by F2 folds. On the northern limb of the fold, the S2 cleavage is a non-penetrative fabric that dips steeply to the east and is associated with shallow north plunging folds. In this area, the bedding is overturned to the southeast and strikes at a high angle to the D2 fabric (fig. 6). On the southern limb of the fold, beds are steeply dipping to vertical and top to the northwest. This evidence suggests that a map-scale F1 synform (southeastward verging, overturned syncline) is responsible for the reversals seen in this area.

In the north-central part of the quadrangle east of Beaver Brook, beds of the SObq unit are upright and dip to the northwest on the northwestern limb of an F1 antiform (southeastward verging, overturned anticline). Topping criteria were not observed on the southeastern limb of this fold where the beds also dip to the northwest, but this structure must be considered more conjectural because of the lack of definitive reversals of tops.

The period of D1 deformation recorded by the F1 folds predates all intrusive igneous activity in the quadrangle. If the $433 \pm 5 \mathrm{Ma}$ age of the Ayer (Zartman and Naylor, 1984) is correct, it suggests that the D1 event was pre $433 \mathrm{Ma}$. This is somewhat older than the earliest phase of Late Silurian Acadian D1 deformation recognized in Maine by Bradley and others (1998) and suggests that either (1) the Acadian is older in the Windham area, (2) that the 433 age needs to be re-evaluted, or (3) that we can not rule out some earlier orogenic event. All of the Ayer rocks intrude the Berwick after D1 but prior to D2 as the Ayer generally contains a well developed S2 foliation, yet cuts the S1 foliation in the Berwick. Muscovite granite (Dmg), binary granite $(\mathrm{Dg})$, and granitic pegmatite $(\mathrm{Dp})$ intrude both the Ayer and the Berwick after D1. The regional trend of the majority of these granitic intrusions is sub-parallel to the D2 fabric (fig. 1, B and C; fig. 2, A, B, and E). Many dikes intrude parallel to the axial surface of F2 folds and are subsequently foliated by the D2 schistosity. Locally thin dikes or sills of granite (Dg) and pegmatite (Dp) intrude sub-parallel to the $\mathrm{S} 1$ foliation but are deformed by F2 folds. More commonly, however, the granites $(\mathrm{Dg})$ and pegmatites $(\mathrm{Dp})$ intrude roughly parallel to the $\mathrm{D} 2$ fabric and contain the S2 foliation. (fig. 7). These syn-tectonic relationships, combined with the $381 \pm 2 \mathrm{Ma}$ age from a foliated biotite granite dike in the area (Lyons and others, 1997), suggest that most of the D2 deformation and intrusion is Acadian in age. At only a single location, within a quarry east of Route 28 in Windham, did we observe a tabular unfolded pegmatite that cut across the D2 fabric. It is possible that this pegmatite is Late Devonian to Permian in age, similar to other late- to post-tectonic granitic rocks in the Milford area of southern New Hampshire (Aleinikoff and others, 1995; Lyons and others, 1997). If these observations are accurate, it is possible that the post-D2 kink bands and D3 fabrics may be attributable to the Alleghanian orogeny. In support of this interpretation, Armstrong and others (1999) reported Alleghanian aged migmatites (c. $275 \mathrm{Ma}$ ) in the Massabesic Gneiss Complex and suggested that this is also the age of D3 deformation in the Pinardville, New Hampshire quadrangle.

\section{REFERENCES CITED}

Aleinikoff, J.N., Walter, M., and Fanning, C.M., 1995, U-Pb ages of zircon, monazite, and sphene from rocks of the Massabesic Gneiss Complex and Berwick Formation, New Hampshire and Massachusetts: Geological Society of America Abstracts with Programs, v. 27, p. 26.

Armstrong, T.R., Aleinikoff, J.N., and Burton, W.C., 1999, Structural and geochronologic constraints on the tectonothermal evolution of the Massabesic Gneiss Complex, southeastern New Hampshire: Geological Society of America Abstracts with Programs, v. 31, no. 2, p. A-2. 
Bradley, D., Tucker, R.D., Lux, D., Harris, A., and McGregor, C., 1998, Migration of the Acadian orogen and foreland basin across the northern Appalachians: U.S. Geological Survey Open-File Report 98-770, 79 p.

Foland, K.A., and Faul, H., 1977, Ages of the White Mountain intrusives - New Hampshire, Vermont, and Maine, USA: American Journal of Science, v. 277, p. 888-904.

Lyons, J.B., and Bothner, W.A., 1989, A transect through the New England Appalachians, with a section on The geology of central New Hamsphire, by J.B. Lyons, and with a section on The geology of southeastern and coastal New Hampshire, by W.A. Bothner, v. 2 of Hanshaw, P.M., ed., Metamorphism and tectonics of eastern and central North America: Washington, D.C., American Geophysical Union, 28th International Geological Congress field trip guidebook, p. T162-1 to T162-64.

Lyons, J.B., Bothner, W.A., Moench, R.H., and Thompson, J.B., Jr., 1997, Bedrock geologic map of New Hampshire: U.S. Geological Survey, scale 1:250,000.

Pankiwskyj, K.A., Ludman, A., Griffin, J.R., and Berry, W.B.N., 1976, Stratigraphic relationships on the southeast limb of the Merrimack synclinorium in central and west-central Maine: Geological Society of America Memoir 146, p. 263-280.

Sriramadas, A., 1966, The geology of the Manchester quadrangle, New Hampshire: New Hampshire Department of Resources and Economic Development Bulletin 2, 78 p., scale 1:62,500.

Zartman, R.E., and Naylor, R.S., 1984, Structural implications of some radiometric ages of igneous rocks in southeastern New England: Geological Society of America Bulletin, v. 95, p. 522-539. 


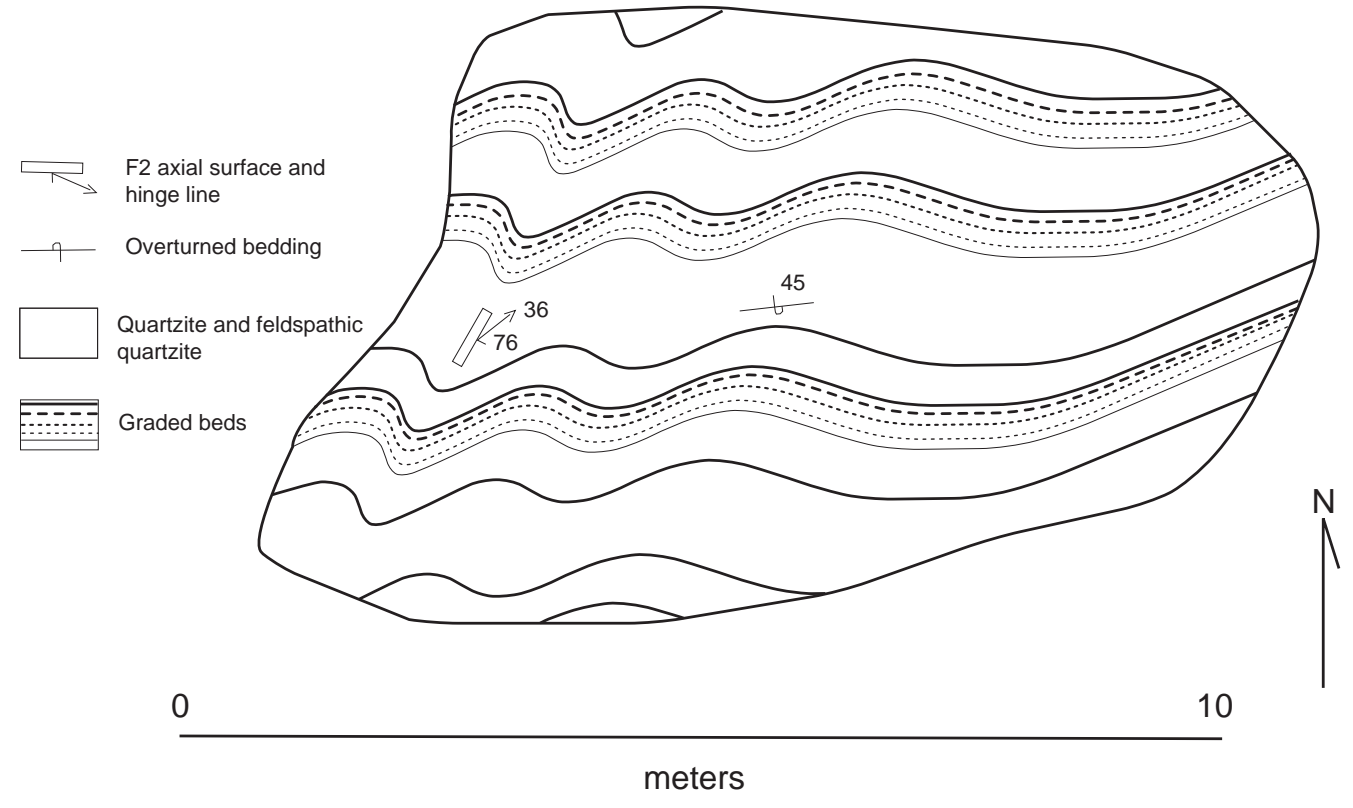

Figure 6. Map view sketch of overturned beds in the SObq unit on the northern limb of a southeastward verging, overturned F1 syncline. The bedding is deformed by upright F2 folds, but these folds cannot explain the overturned bedding requiring a major F1 fold. Sketch of outcrop located in Salem, $0.7 \mathrm{~km}$ at $027^{\circ}$ from the intersection of Brady Avenue and Route 38.

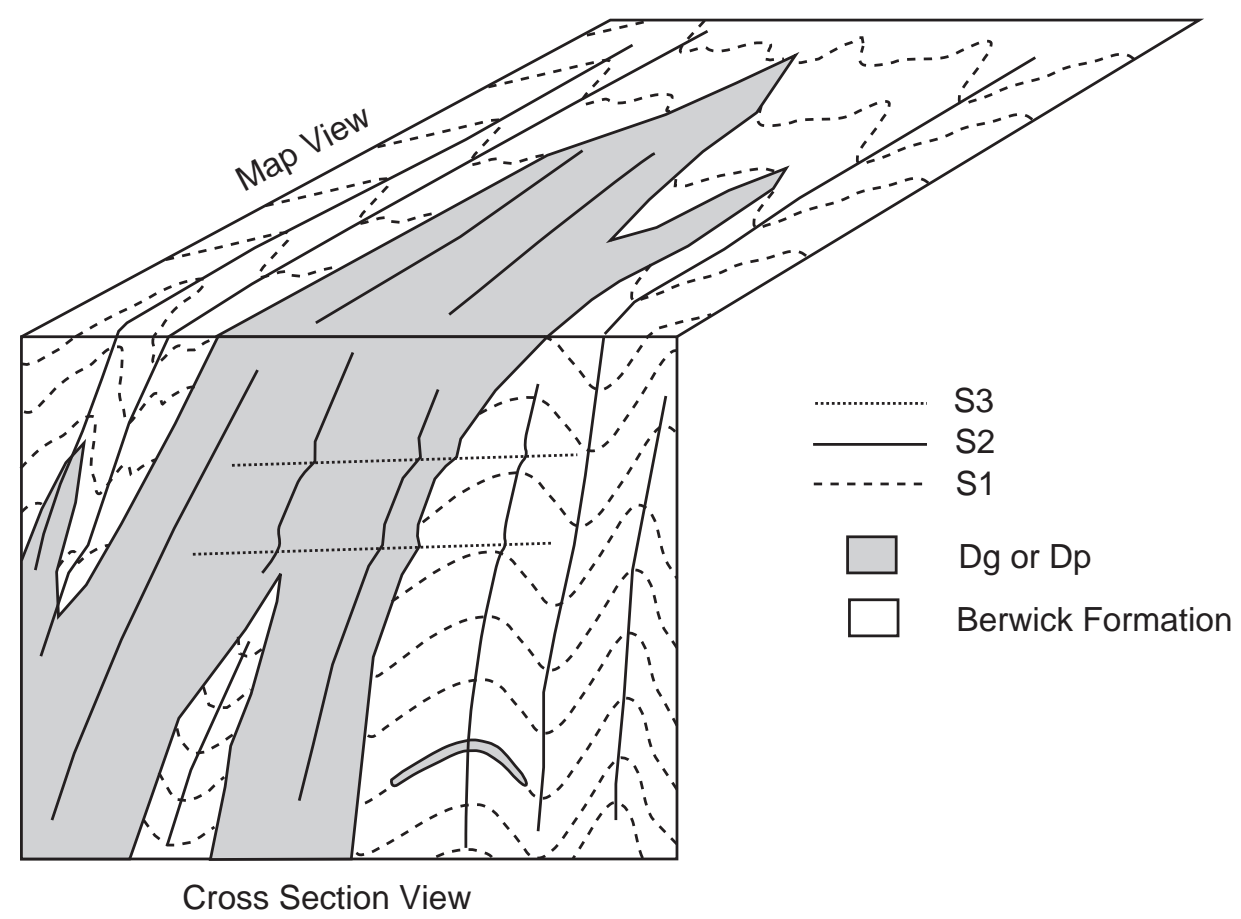

Figure 7. Structural relationships between tectonic fabrics and grantitic and pegmatitic rocks. Locally, granitic sills occur sub-parallel to the S1 foliation and are deformed by F2 folds. The majority of the Devonian granitic rocks (Dg and Dp), however, intrude sub-parallel to the axial surfaces of F2 folds and are subsequently foliated by S2. This suggests that most of the granitic intrusions are syn-tectonic during D2. The late sub-horizontal S3 cleavage deforms all older fabrics. 


\section{DESCRIPTION OF MAP UNITS}

(Minerals listed in order of increasing abundance)

Post-Metamorphic Intrusive Rocks

Rocks of the White Mountain Plutonic-Volcanic Suite

Md \& Mdp

Diabase and lamprophyre dikes (Mesozoic) - Black to dark-gray and greenish black, brown weathering, fine- to medium-grained, ophitic to porphyritic diabase or lamprophyre dikes. Dikes range in thickness from several $\mathrm{cm}$ to approximately $40 \mathrm{~m}$. The thinner dikes, generally less than $50 \mathrm{~cm}$, are aphanitic and may locally contain phenocrysts of olivine, hornblende, pyroxene, and plagioclase. The thicker diabasic dikes (Mdp) are porphyritic with large (up to $1 \mathrm{~cm}$ ) phenocrysts of plagioclase in addition to phenocrysts found in the thinner dikes. Dikes contain accessory serpentine, chlorite, and magnetite. Dikes locally contain amygdules filled with calcite or dolomite. Where carbonate minerals are relatively abundant, the dikes weather to an earthy black residuum.

Syn- to Post-Metamorphic Intrusive Rocks

Rocks of the New Hampshire Plutonic Suite

Dp Pegmatite (Devonian?) - Light-gray to white, very coarse-grained +/-muscovite-biotitequartz-albite-microcline pegmatite and coarse-grained granitic pegmatite. Contains accessory apatite and zircon. Locally contains garnet. Dikes vary from folded and weakly foliated irregular masses to tabular, unfoliated bodies. Occurs as outcrop- and map-scale dikes that range from several $\mathrm{cm}$ thick to $\mathrm{km}$-scale intrusions.

Dg Binary granite and granitic pegmatite (Devonian) - Light-gray to white, medium- to very coarse-grained, foliated, muscovite-biotite-quartz-albite-microcline binary granite and granitic pegmatite. Contains accessory apatite and zircon. Locally contains garnet. Dikes vary from folded, foliated irregular masses to tabular, weakly foliated bodies. Occurs as outcrop- and map-scale dikes that range from several $\mathrm{cm}$ thick to $\mathrm{km}$-scale intrusions.

Dmg Muscovite granite (Devonian) - Light-gray to white, slightly rusty orange weathering, foliated, muscovite-quartz-albite-microcline granite. Locally contains biotite and garnet. Contains accessory apatite and zircon. Occurs as large km-scale dikes of the Hudson pluton in the northwestern part of the map area. 
Rocks of the Ayer Granodiorite (Silurian)

Sag Porphyritic granite to granodiorite - Light-gray to gray weathering, black and white, coarse- to medium-grained, well foliated, porphyritic biotite-quartz-microcline-oligoclase granite gneiss to quartz-microcline-biotite-oligoclase granodiorite gneiss. Contains minor muscovite and hornblende and accessory zircon, sphene, apatite, magnetite, and garnet. Discontinuous segregations of biotite define a gneissosity that wraps around and cuts through granular aggregates of quartz and feldspar. The aggregates are locally cored by anhedral to subhedral phenocrysts of microcline that display carlsbad twinning but lack well formed crystal faces. Phenocrysts of white to gray microcline range up to $3 \mathrm{~cm}$ in length, but are more typically 1 to $2 \mathrm{~cm}$ long. Where strongly foliated, microcline phenocrysts are aligned in the plane of gneissosity, and the rock is an augen gneiss.

Sagd Granodiorite - Medium- to dark-gray or black, medium- to coarse-grained hornblendequartz-microcline-biotite-oligoclase schist and dark-gray to black, equigranular, mediumto coarse-grained, well foliated hornblende-quartz-microcline-biotite-oligoclase granodiorite gneiss. Contains accessory zircon, sphene, apatite, magnetite, and garnet. Locally near the contact with Sag, darker layers of Sagd are interleaved with the porphyritic gneiss of Sag. These layers of granodiorite, $15 \mathrm{~cm}$ to $30 \mathrm{~cm}$ thick, show sharp boundaries with the porphyritic gneiss and are interpreted as flow banding.

Sagdg Garnetiferous granodiorite - Medium- to dark-gray or black, coarse- to medium-grained, homogenous, well-foliated \pm chlorite-garnet-hornblende-quartz-microcline-biotiteoligoclase granodiorite gneiss. Ubiquitous red garnet occurs as conspicuous porphyroblasts up to $1.5 \mathrm{~cm}$ in diameter. Contains accessory zircon, sphene, apatite, and magnetite.

Sad Diorite - Equigranular, medium- to coarse-grained, very dark green to black, biotitehornblende-oligoclase-andesine diorite. Contains trace quartz and microcline. Contains accessory chlorite, zircon, sphene, and magnetite. Equidimensional grains range in size from 2 to $10 \mathrm{~mm}$ in diameter. Commonly interleaved with Sagd and Sob. Locally, finegrained diorite xenoliths to $10 \mathrm{~cm}$ in diameter are surrounded by coarser diorite. Locally a dark-gray, medium-grained muscovite-biotite-amphibole-plagioclase gneiss crops out within the diorite.

Metasedimentary Rocks of the Merrimack Trough

Berwick Formation (Ordovician and Silurian)

$\mathrm{SOb}$ Biotite-plagioclase-quartz granofels and schist, and calc-silicate rocks - Gray to darkgray or rusty weathering, medium- to light-gray, fine- to medium-grained biotite- 
plagioclase-quartz granofels intercalated with purplish gray to pale-green, whiteweathering, dark-green-spotted, \pm calcite \pm dolomite-epidote-clinozoisite-quartz \pm diopsideactinolite-hornblende-plagioclase calc-silicate gneiss. The granofels contains trace to accessory epidote, diopside, actinolite, hornblende. Contains accessory muscovite, chlorite, magnetite, sphene, apatite, and garnet. The percentage of calc-silicate rock varies within the unit from approximately 5 percent, or less, up to 30 percent, and locally up to 50 percent. Calcite and dolomite are present in trace quantities in the garnet zone. Calc-silicate gneiss locally occurs as distinct layers up to $30 \mathrm{~cm}$ thick or as disarticulated, boudinaged lenses and pods within the granofels. Centimeter-scale quartz veins and white-weathering calc-slicate and quartz segregations, both syn- and post-deformation, cut the granofels. Locally, finely laminated ( 2 to $3 \mathrm{~mm}$ thick) plagioclase-quartz layers alternating with thin planes of biotite and/or calc-silicate minerals produce a pinstripe texture within SOb. Locally, light-gray granofels displays thicker (0.5 to $1.5 \mathrm{~cm}$ thick) biotite-plagioclase-quartz laminations separated by $0.5 \mathrm{~mm}$ thick biotite-rich or calcsilicate partings.

SObw Well-bedded biotite-plagioclase-quartz granofels and schist, and calc-silicate rocks Distinctly well-bedded, dark purplish gray to gray, rusty weathering, chlorite-muscovitebiotite-plagioclase-quartz granofels and schist interlayered with pale-green, whiteweathering \pm calcite \pm dolomite-epidote-clinozoisite-biotite-quartz-actinolite-plagioclase calc-silicate granofels or gneiss. Calc-silicate rocks occur as distinct layers, or beds, up to $10 \mathrm{~cm}$ thick, or as disarticulated lenses and pods within the biotite-plagioclase-quartz granofels. The percentage of calc-silicate rock is approximately 5 percent. Calcite and dolomite are present in trace quantities in the biotite zone. The unit contains muscovitechlorite-biotite-quartz \pm calcite \pm dolomite veins. Bedding is typically $5-15 \mathrm{~cm}$ thick but ranges up to $40 \mathrm{~cm}$ thick, and is locally graded.

SObq Quartzite, biotite-plagioclase-quartz granofels, and calc-silicate rocks - Light-gray, feldspathic quartzite, calcareous quartzite, and calc-silicate bearing quartzite interlayered with dark purplish gray to gray, rusty weathering, biotite-plagioclase-quartz granofels and schist and pale-green, white weathering, \pm calcite \pm dolomite-epidoteclinozoisite \pm diopside-quartz-actinolite-hornblende-plagioclase calc-silicate rock similar to SOb. Plagioclase in the feldspathic quartzite consists of albite, oligoclase, and abundant highly sausseritized plagioclase of undetermined composition. Quartzite layers are typically well bedded, and bed thickness ranges from several $\mathrm{cm}$ to $1 \mathrm{~m}$. Granofels layers are locally well bedded and display excellent graded bedding. 